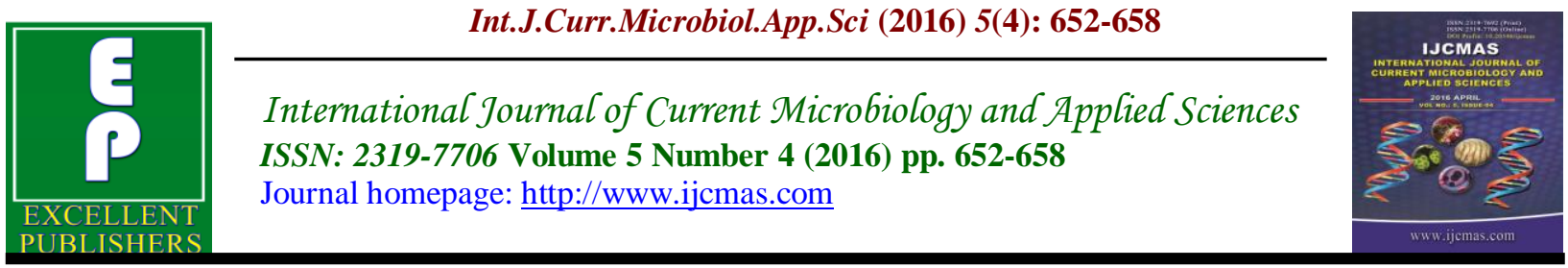

Original Research Article

http://dx.doi.org/10.20546/ijcmas.2016.504.074

\title{
Screening and Characterization of Heavy Metal Resistant Fungi for its Prospects in Bioremediation of Contaminated Soil
}

\author{
H. Desai ${ }^{1 *}$, D. Patel ${ }^{1}$ and B. Joshi ${ }^{2}$ \\ ${ }^{1}$ C. G. Bhakta Institute of Biotechnology, Uka Tarsadia University, \\ Bardoli, Surat (Dist) Gujarat, India \\ ${ }^{2}$ Department of Food Quality Assurance, College of Food Processing and Bioenergy, \\ Anand Agriculture University, Anand, Gujarat, India \\ *Corresponding author
}

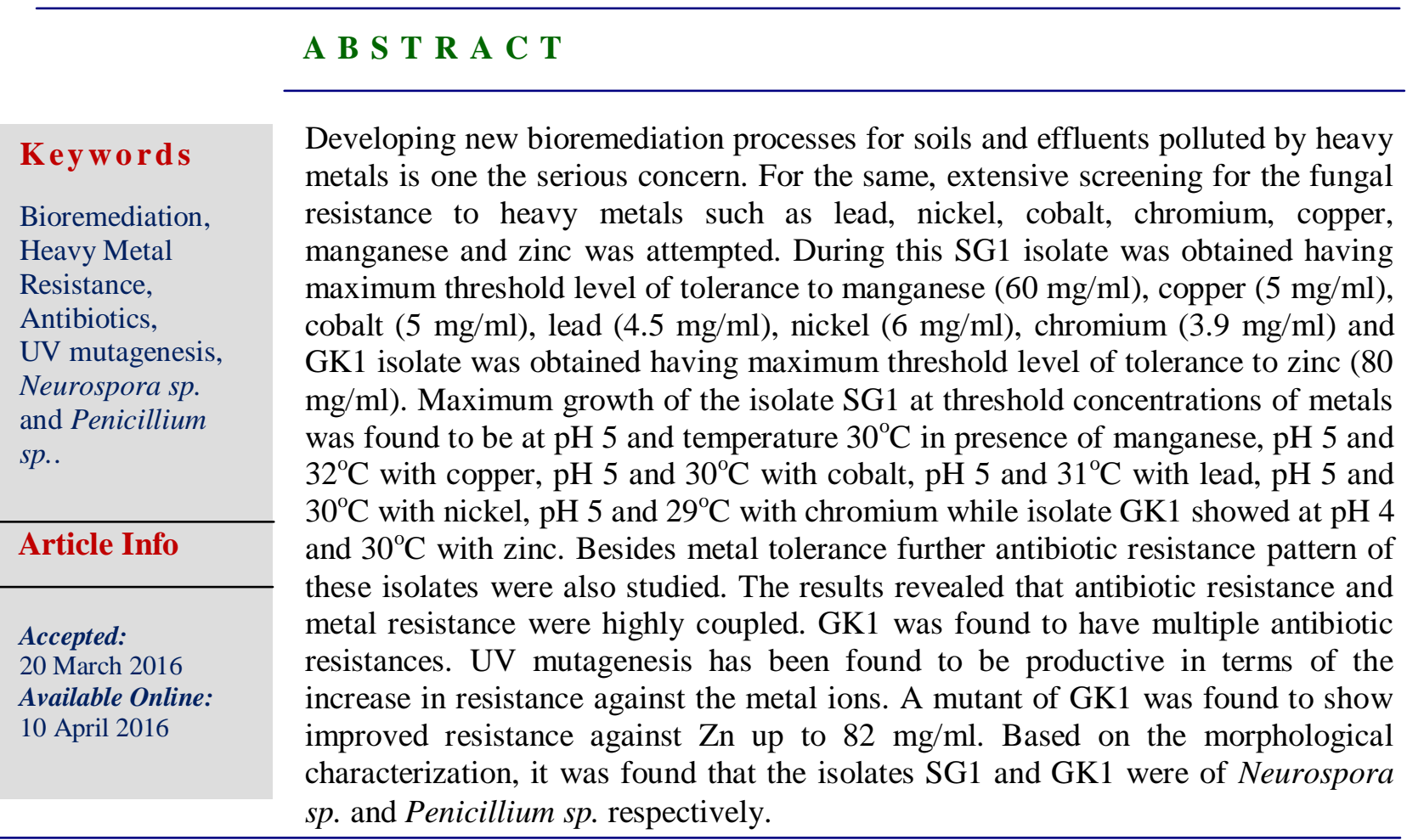

\section{Introduction}

Heavy metals and trace elements in subsurface environments come from natural and anthropogenic sources. The intense petrochemical works, rapid industrialization and urbanization during last two decades increase this pollution enormously. Heavy metal pollution of the biosphere has received huge concern due to its toxicity, abundance, persistence and subsequent accumulation in environment. These toxic heavy metals in air, soil and water are global problems that are a growing threat to humanity (Dong et al., 2010). 
Typical sewage contains oxygen-demanding materials, grease, oil, scum, pathogenic bacteria, viruses, pesticides, refractory organic compounds and heavy metals (Giller et al., 2009). Sewage; on treatments and disposal in to open environment results in accumulation of large amount of sludge, which are disposed off worldwide through land disposal. One of the main concerns in the land disposal of sludge is presence of toxic heavy metals which gets magnified during various physicochemical and biological interactions occurring in sludge treatment.

Another major concern over the presence of these heavy metals in the environment is their non-biodegradability and consequent persistence. Since, the presence of heavy metals can pose a long term environmental hazard once accumulated in land with time (Mc-Bride, 1995), reduction or elimination of heavy metals from these sludge before land application is necessary (Mc-Bride, 1995). The commonest way of disposing waste water sludge and solid waste is incineration, which results in heat and electricity production, as well as a significant reduction in the waste volume. However, produced ash is a problem (Fedge et al., 2010).

Accumulation of metals in living organisms is the cause of serious health problems, by interfering with, our normal body functions. Some of these metals are useful to the body in low concentrations like arsenic, copper, iron and nickel but are toxic at high concentrations. Other metals like aluminum, beryllium, cadmium, lead and mercury have no biological functions and are highly toxic disrupting bodily functions to a large extent. They disrupt bodily functions by accumulating in vital organs and glands in the human body such as in the heart, brain, kidney, bone and liver. They also displace vital nutritional minerals from their proper place in the body to provide biological functions e.g., lead or cadmium displaces calcium in an enzyme reaction disrupting the enzyme reaction to a large extent. As their impact in the body, is at such basic levels that they are the causal factors in multiple health problems. Metal causes genotoxicity as they affect the DNA and immunotoxicity as they are major irritants to the body. The genomic instability by these metals induces cancer (Leonard et al., 2004).

\section{Materials and Methods}

\section{Sampling and Sample Preparation}

The effluent samples were collected from the contaminated sites of Sachin GIDC, Navsari GIDC, Navsari Udyognagar, Pandesara GIDC, Dabhoi khadi and Gabheni khadi in Gujarat, India. $1 \mathrm{ml}$ of samples was mixed with $9 \mathrm{ml}$ of diluents individually, centrifuged at $1200 \mathrm{rpm}$ for $3 \mathrm{~min}$, and supernatants were used for isolation of metal resistant fungi.

\section{Isolation of Fungi from the Environmental Samples}

The samples prepared from the effluents of contaminated sites were inoculated to Potato Dextrose Broth (PDB). PDB was prepared using $250 \mathrm{~g}$ of potato boiled in $100 \mathrm{ml}$ of distilled water for $30 \mathrm{~min}$ and the filtrate was mixed with $20 \mathrm{~g}$ of dextrose and incubated at $30-35^{\circ} \mathrm{C}$ for a week. After incubation larger identical colonies from each flask were isolated. These isolates were further employed for heavy metal resistance studies (Shankar Congeevaram et al., 2006).

\section{Screening for Metal Resistance}

All the fungal isolates were evaluated for their metal resistance against varying 
concentrations of heavy metals that included copper as $\mathrm{CuSO}_{4} * 5 \mathrm{H}_{2} \mathrm{O}$, zinc as $\mathrm{ZnSO}_{4}$, manganese as $\mathrm{MnCl}_{2}$, cobalt as $\mathrm{CoCl}_{2}$, lead as $\mathrm{Pb}\left(\mathrm{NO}_{3}\right)_{2}$, nickel as $\mathrm{NiCl}_{2}$ and chromium as $\mathrm{K}_{2} \mathrm{Cr}_{2} \mathrm{O}_{7}$ (Nazareth and Marbaniang, 2008).

\section{pH and Temperature Optimization}

The fungal isolates were inoculated into a series of $250 \mathrm{ml}$ conical flasks containing above described metals. The $\mathrm{pH}$ was varied from 3 to $8(3,4,5,6,7$ and 8$)$. The $\mathrm{pH}$ of the medium was adjusted using $0.1 \mathrm{~N} \mathrm{HCl}$ or $0.1 \mathrm{~N} \mathrm{NaOH}$. Studies on optimal temperature for the selected fungal isolates were carried out by growth at different temperatures (29, $30,31,32,33,34$ and $35^{\circ} \mathrm{C}$ ) in the presence of metal ions at threshold concentration. These were incubated on rotary shaker (120 rpm) in a temperature controlled water bath for $48 \mathrm{~h}$. The optimum $\mathrm{pH}$ and temperature was evaluated based upon the biomass production by each selected fungal isolates (Shankar Congeevaram et al; 2006).

\section{Resistance to Antibiotics by Metal Resistant Fungal Isolates}

The isolates were evaluated for its resistance to antibiotics by disc diffusion method. The PDA $(1.5 \%)$ was prepared. Then it was overlayed by PDA $(0.8 \%)$ mixed with fungal isolates under examination. After solidification, antibiotic paper disc (HexaDisc HI-MEDIA) was placed over it. The plates were incubated at $4^{\circ} \mathrm{C}$ for $30 \mathrm{~min}$ for diffusion of respective antibiotics followed by the incubation at $30^{\circ} \mathrm{C}$ for $24 \mathrm{hrs}$. The zone of inhibition was measured for each plate.

\section{UV Mutagenesis to Improve Threshold for Metal Resistance of Selected Fungal Isolates}

Selected fungal isolates were exposed to UV radiation for $15 \min 20 \mathrm{~min} 25 \mathrm{~min}$ and 30 min in UV chamber. The survival populations after each exposure were further screened for improved metal resistance. The mutants were inoculated in PDB with respective metal at concentration higher than that of threshold level for 3 days at $30^{\circ} \mathrm{C}$ in presence of the metal.

\section{Characterization of Metal Resistant Fungal Isolates}

Metal resistant fungal isolates were studied for its morphological features under the compound microscope. The isolates were mounted with the help of lactophenol blue (phenol $20 \mathrm{ml}$, lactic acid $20 \mathrm{ml}$, Glycerol 40 $\mathrm{ml}$, Distilled water $20 \mathrm{ml}, 0.05 \%$ Methyl blue).

\section{Results and Discussion}

\section{Isolation of Fungi}

Eight fungi were isolated from the different sources (Sachin GIDC, Navsari GIDC, Navsari Udyognagar, Pandesara GIDC, Dabhoi khadi and Gabheni khadi). They were designated as SG1, SG2, NG1, NG2, PG1, DK1, GK1 and GK2. The results of screening for metal resistant fungi are summarized in Table 1.

\section{Characteristics of Metal Resistant Fungal Isolates}

Determination of MIC: Isolate SG1 was evaluated for the resistance against $\mathrm{Mn}, \mathrm{Cu}$, $\mathrm{Co}, \mathrm{Pb}, \mathrm{Ni}$ and $\mathrm{Cr}$ metal ions while isolate GK1 was evaluated for the resistance against $\mathrm{Zn}$ metal ion.

The threshold level of resistance against metal ions $\mathrm{Mn}, \mathrm{Cu}, \mathrm{Co}, \mathrm{Pb}, \mathrm{Ni}$ and $\mathrm{Cr}$ were $60 \mathrm{mg} / \mathrm{ml}, 5 \mathrm{mg} / \mathrm{ml}, 5 \mathrm{mg} / \mathrm{ml}, 4.5 \mathrm{mg} / \mathrm{ml}, 6$ $\mathrm{mg} / \mathrm{ml}$ and $3.9 \mathrm{mg} / \mathrm{ml}$ respectively for SG1 while resistance against Zn by GK1 was 80 $\mathrm{mg} / \mathrm{ml}$. 


\section{pH Optima for Metal Resistance}

Studies in the past revealed that the fungal isolates shows higher resistance in acidic range of the $\mathrm{pH}$ (Juan Maldonado et al., 2010). Attempt was made to evaluate the optimum $\mathrm{pH}$ for the maximum resistance of metal ions by selected isolates SG1 and GK1. Optimum $\mathrm{pH}$ for maximum resistance against metal ions $\mathrm{Mn}, \mathrm{Cu}, \mathrm{Co}, \mathrm{Pb}, \mathrm{Ni}$ and $\mathrm{Cr}$ was found to be 5 except for $\mathrm{Zn}$ it was 4 . The results are summarized in Fig 2.

\section{Temperature Optima for Metal Resistance}

Various studies in the past have shown that the resistances against the metal ions by isolates were closely related to the temperature of the environment (Juan Maldonado et al., 2010). In same context, attempt was made to investigate optimum temperature for resistance against metal ions. Optimum temperatures for maximum resistance against metal ions $\mathrm{Mn}, \mathrm{Zn}, \mathrm{Co}, \mathrm{Ni}$ were found to be $30^{\circ} \mathrm{C}$ while for $\mathrm{Cr}, \mathrm{Cu}$ and $\mathrm{Pb}$ they were $29^{\circ} \mathrm{C}, 32^{\circ} \mathrm{C}$ and $31^{\circ} \mathrm{C}$ respectively, as summarized in Fig 3 below.

\section{Evaluation of Antibiotic Susceptibility}

Studies revealed that metal resistance is correlated with antibiotic resistance (Zeng Xiao-xi et al., 2009). In same context, the attempt was made to investigate antibiotic resistance pattern by selected potential isolates against six different antifungal antibiotics (Plate 1).

GK1 isolate was sensitive to Nystatin, Amphotericin B and Ketoconazole antibiotics as there was no zone of inhibition. SG1 was found to show resistance against all of them as shown in Table 2.

\section{UV Mutagenesis for Improvement of Threshold Limit of Metal Resistance}

UV mutagenesis has been found to be productive in terms of the increase in resistance against the metal ions (Naveenkumar et al., 2010). Both isolates were treated with UV for mutagenesis and then the mutant population were subjected to assessment of whether the threshold limit for metal resistance was improved compared to wild type isolate or not. After UV treatment, no significant change in the resistance of metal ions was observed compared to wild type except for $\mathrm{Zn}$ metal ion. A mutant of GK1 was found to show improved resistance against $\mathrm{Zn}$ up to $82 \mathrm{mg} / \mathrm{ml}$ compared to 80 $\mathrm{mg} / \mathrm{ml}$ of wild type.

Table.1 Isolation of Fungi from Different Sources

\begin{tabular}{ccc}
\hline Sample site & Isolation method & Isolates \\
\hline Sachin GIDC & Direct & $2($ SG 1-2) \\
Navsari GIDC & Direct & 2 (NG 1-2) \\
Navsari Udyognagar & Direct & Nil \\
Pandesara GIDC & Direct & 1 (PG 1) \\
Dabhoi khadi & Direct & 1 (DK 1) \\
Gabheni khadi & Direct & $2($ GK 1-2) \\
\hline
\end{tabular}


Table.2 Antibiotic Resistance of Metal Resistant Fungal Isolates

\begin{tabular}{lcc}
\hline \multicolumn{1}{c}{ ANTIBIOTICS } & $\begin{array}{c}\text { ZONE OF INHIBITION } \\
\text { SG1 }(\mathrm{CM})\end{array}$ & $\begin{array}{c}\text { ZONE OF INHIBITION } \\
\text { GK1 }(\mathrm{CM})\end{array}$ \\
\hline Nystatin (Ns) & - & 1.9 \\
Amphotericin B (Ap) & - & 1.1 \\
Ketoconazole $(\mathrm{Kt})$ & - & 1.4 \\
Clotrimazole $(\mathrm{Cc})$ & - & - \\
Fluconazole $(\mathrm{Fu})$ & - & - \\
Itraconazole $(\mathrm{It})$ & - & - \\
\hline
\end{tabular}

Fig.1 Threshold Level of the Metal Resistance by Isolates SG1 and GK1

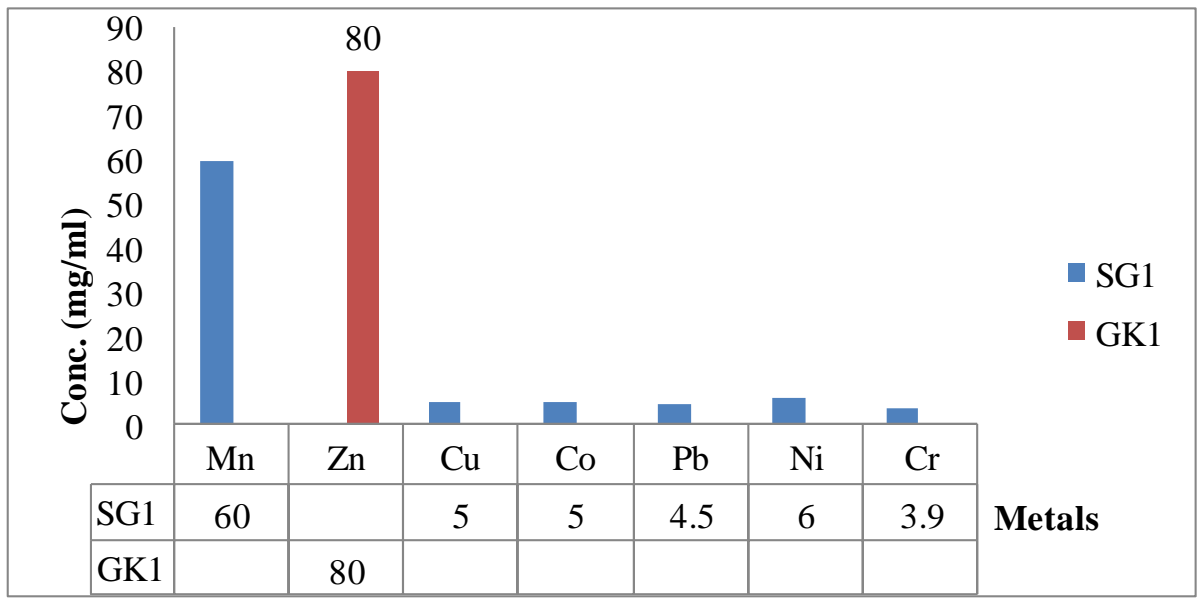

Fig.2 pH Optima for Different Metals

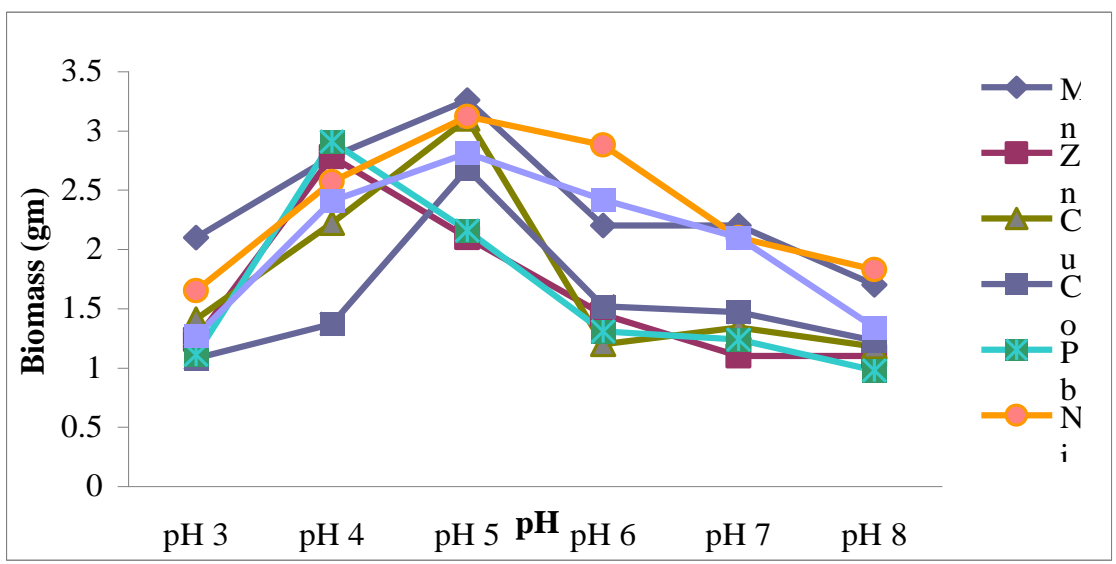


Fig.3 Temperature Optima for Different Metals

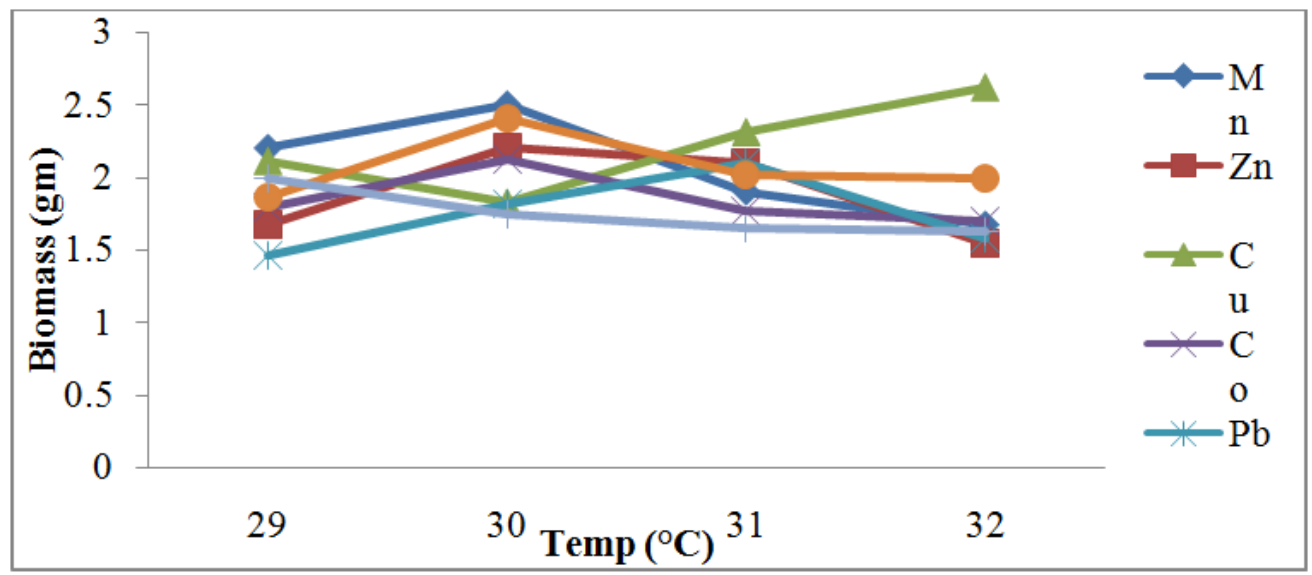

Plate.1 Antibiotic Resistance of Selected Fungal Isolates: A.SG1; B.GK1
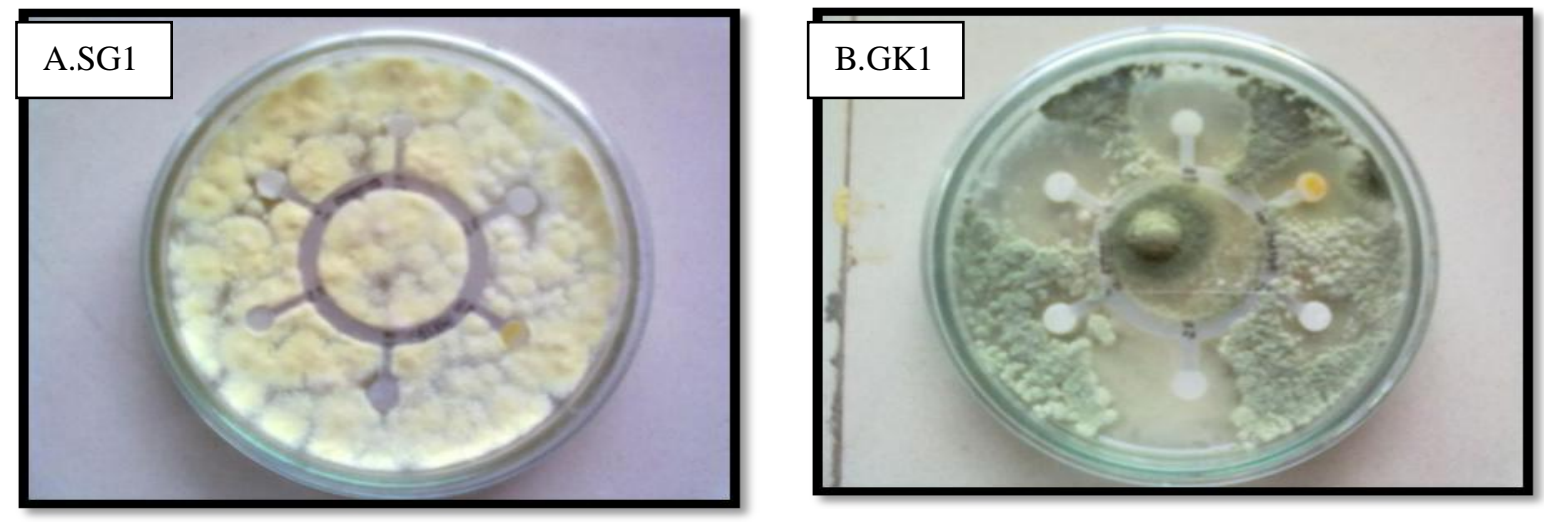

\section{Morphological Characteristics}

Morphological characteristics of the isolates SG1 and GK1 were observed under the compound microscope. SG1 was found to be Neurospora sp. as it shown clear septate hyphae with large masses of ovate spores which are air-dispersed while GK1 resembled Penicillium sp. giving small, round spores borne in "brush-like" formations when mounted with lactophenol.

In conclusion, Species of Neurospora and Penicillium obtained during screening found to show significant resistance for metals. The threshold limit for metal resistance by Neurospora $s p$. is $60 \mathrm{mg} / \mathrm{ml}, 5 \mathrm{mg} / \mathrm{ml}, 5$ $\mathrm{mg} / \mathrm{ml}, 4.5 \mathrm{mg} / \mathrm{ml}, 6 \mathrm{mg} / \mathrm{ml}, 3.9 \mathrm{mg} / \mathrm{ml}$ to manganese, copper, cobalt, lead, nickel, chromium respectively. While Penicillium $s p$. was resistant to zinc up to $80 \mathrm{mg} / \mathrm{ml}$ concentration. Further UV mutagenesis yield a mutant of Penicillium $s p$. with improved resistance to zinc up to $82 \mathrm{mg} / \mathrm{ml}$. These fungal isolates were also versatile as also showed the antibiotic resistance. These studies found to show their prospect for bioremediation of metal contaminated sites for cleanup of environment.

\section{References}

Dong, X., Li, C., Li, J., Wang, J., Liu, S., Ye, B. 2010. A novel approach for 
soil contamination assessment from heavy metal pollution: A linkage between discharge and adsorption. $J$. Hazard. Mat., 175: 1022-1030.

Fedge, K.K., Ekberg, C.C., Skarnemark, G., Steenari, B.M. 2010. Removal of hazardous metals from MSW fly ash: An evaluation of ash. J. Hazard. Mat., 173: 310-317.

Giller, K.E., Witter, E., McGrath, S.P. 2009. Heavy metals and soil microbes. Soil Biol. Biochem., 41: 2031-2037.

Juan Maldonado, et al. 2010. Isolation and identification of a bacterium with high tolerance to lead and copper from a marine microbial mat in Spain, Ann. Microbiol., 60: 113-120.

Leonard, S.S., Marres, G.K., Shi, X.L. 2004. Metal-induced oxidative stress and signal transduction. Free Rad. Biol. Med., 37: 1921-1942.

Mc-Bride, M.B. 1995. Toxic metal accumulation from agricultural use of sludge: Are USEPA regulations protective. J. Environ. Qual., 24: 518.

Naveenkumar, et al. 2010. Isolation, Screening and In Vitro Mutational Assessment of Indigenous Soil bacteria for Enhanced Capability in Petroleum Degradation, Int. J. Env. Sci., 1: 43-45.

Shankar Congeevaram, Sridevi Dhanarani, Joonhong Park, Michael Dexilin, Kaliannan Thamaraiselvi. 2007. Biosorption of chromium and nickel by heavy metal resistant fungal and bacterial isolates. J. Hazard. Mat., 146: 270-277.

Zeng Xiao-xi, et al. 2009. Isolation, identification and characterization of cadmium-resistant Pseudomonas aeruginosa strain E1 J. Cent. South Univ. Technol., 16: 0416-0421.

\section{How to cite this article:}

Desai, H., D. Patel and Joshi, B. 2016. Screening and Characterization of Heavy Metal Resistant Fungi for its Prospects in Bioremediation of Contaminated Soil. Int.J.Curr.Microbiol.App.Sci.5(4): 78-94. doi: http://dx.doi.org/10.20546/ijcmas.2016.504.074 